\title{
PENGARUH PROFITABILITAS, SRUKTUR MODAL, DAN LIKUIDITAS TERHADAP NILAI PERUSAHAAN
}

\author{
EFFECT OF PROFITABILITY, CAPITAL SRUCTURES, AND \\ LIQUIDITY TO THE VALUE OF THE COMPANY
}

\section{Ignatius Leonardus Lubis ${ }^{* 11}$, Bonar M Sinaga ${ }^{* *}$, dan Hendro Sasongko $\left.{ }^{* * *}\right)$}

${ }^{*}$ Sekolah Bisnis, Institut Pertanian Bogor

Jl. Raya Pajajaran, Bogor 16151

**) Departemen Ekonomi Sumberdaya dan Lingkungan, Fakultas Ekonomi dan Manajemen, Institut Pertanian Bogor Jl. Agatis Kampus IPB Darmaga Gd. Fakultas Ekonomi dan Manajemen W3L2 Darmaga Bogor 16880

$\left.{ }^{* * *}\right)$ Fakultas Ekonomi Universitas Pakuan

Jl. Pakuan PO Box 452, Bogor 16143

\begin{abstract}
The purpose of this study was to determine the influence and formulate recommendations from the ROE, DER san $L D R$. This research is a causal with quantitative approach. Independent variable is the profitability, capital structure and liquidity, while the dependent variable is the value of the company. Analysis of the data used is inferential statistical analysis. This study uses panel data regression analysis were processed using software eviews 8.From the results of the study stated that ROE, DER and LDR had effected $P B V$ simultaneous and variable of $R O E$ has positive and significant to company value.
\end{abstract}

Keywords: capital structure, corporate value, inferential statistic, liquidity, profitability

\begin{abstract}
Abstrak: Tujuan penelitian ini adalah untuk mengetahui dan memformulasi rekomendasi pengaruh profitabilitas, struktur modal dan likuiditas terhadap nilai perusahaan pada bank yang go public periode tahun 2011-2014.Analisis data yang digunakan adalah analisis statistic inferensial. Penelitian ini juga menggunakan analisis regresi data panel. Dari hasil penelitian menyatakan bahwa return on equity (ROE) berpengaruh positif dan signifikan terhadap PBV sehingga perusahaan perlu memperhatikan dan terus meningkatkan ROE dengan cara mengambangkan prospek kegiatan dalam rangka untuk peningkatan laba. Nilai probabilitas terbesar adalah ROE jika dibandingkan dengan variabel independen lainnya. Oleh karena itu ROE dapat dipakai sebagai prediktor dalam memprediksi tentang nilai perusahaan.
\end{abstract}

Kata kunci: likuiditas, regresi, profitabilitas, statistik inferensiala, struktur modal

\footnotetext{
${ }^{1}$ Alamat Korespondensi:

Email: sibuloel@yahoo.com.
} 


\section{PENDAHULUAN}

Sektor perbankan memiliki peran yang penting dalam memacu pembangunan ekonomi ke arah peningkatan kesejahteraan rakyat banyak. Disamping perananannya dalam penyelenggaraan lalu lintas pembayaran serta fungsinya sebagai lembaga intermediasi, sektor perbankan juga sebagai alat transmisi kebijakan moneter. Peran besar sektor perbankan ini menyebabkan setiap perubahan yang terjadi pada sektor perbankan akan menimbulkan dampak terhadap sektor lainnya.

Maksimalisasi nilai perusahaan dalam meningkatkan kemakmuran pemegang saham serta meningkatkan kinerja merupakan tujuan dan kewajiban dari perusahaan (Andini, 2014). Dominick (2005) menyatakan bahwa tujuan pendirian perusahaan adalah untuk memaksimalkan kekayaan atau nilai perusahaan. Memaksimalkan nilai perusahaan sangat penting artinya bagi perusahaan, karena maksimalisasi nilai perusahaan berarti memaksimalkan kemakmuran pemegang saham yang merupakan tujuan utama perusahaan. Sedangkan nilai perusahaan akan tercermin dari harga pasar sahamnya (Wahyudi dan Pawestri, 2006). Harga saham ditunjukkan dengan nilai kapitalisasi pasar. Nilai perusahaan juga dapat dilihat dari price book value (PBV) yang merupakan perbandingan antara harga saham dengan nilai buku per lembar saham (Robert, 1997). Pada tahun 2011-2014, nilai rata-rata PBV bank yang go public mengalami penurunan. Penurunan nilai perusahaan dapat dipengaruhi oleh beberapa faktor. Faktor-faktor tersebut dapat berasal dari internal maupun eksternal perusahaan. Faktor-faktor internal perusahaan yang dapat memengaruhi nilai perusahaan antara lain profitabilitas, struktur modal, dan likuiditas.

Semakin baik kinerja keuangan suatu perusahaan pasti semakin baik pula nilai perusahaannya (Triagustina et al. 2014). Profitabilitas merupakan salah satu faktor yang secara teoritis menentukan nilai suatu perusahaan. Perusahaan yang mampu menghasilkan laba besar dan stabil akan menarik para investor, karena secara otomatis akan menguntungkan investor. Kemampuan perusahaan yang besar untuk menghasilkan laba juga menunjukkan manajemen perusahaan yang baik, sehingga menumbuhkan kepercayaan pada investor. Kepercayaan investor ini pada akhirnya dapat menjadi instrumen yang paling efektif untuk mengangkat harga saham perusahaan. Peningkatan harga saham sama artinya meningkatkan nilai perusahaan, sehingga lebih lanjut dapat menjamin kemakmuran pemegang saham. Lain halnya jika perusahaan tidak memiliki kemampuan yang baik dalam menghasilkan laba, maka para investor akan ragu atau tidak percaya untuk menanamkan sahamnya. Ketidakpercayaan ini menjadi pemicu yang serius penurunan harga saham perusahaan, sehingga nilai perusahaan juga akan menjadi jatuh.

Menurut Saidi (2004), profitabilitas adalah kemampuan perusahaan dalam memperoleh laba. Menurut Soliha dan Taswan (2002), profitabilitas adalah tingkat keuntungan bersih yang mampu diraih oleh perusahaan pada saat menjalankan operasinya. Profitabilitas perusahaan dapat dilihat melalui rasio-rasio profitabilitas seperti Return on Asset (ROA), Return on Equity (ROE), dan Return on Investment (ROI). Rasio profitabilitas yang berfungsi dan sering digunakan untuk memprediksi harga saham atau return saham adalah ROA atau ROI. ROA atau ROI digunakan untuk mengukur efektivitas perusahaan dalam menghasilkan keuntungan dengan memanfaatkan aktiva yang dimilikinya. Menurut Sujoko dan Soebiantoro (2007), profitabilitas menjadi pertimbangan yang cukup penting bagi investor dalam keputusan investasi. Profitabilitas yang tinggi menunjukkan prospek perusahaan yang baik sehingga investor akan merespon positif sinyal tersebut dan nilai perusahaan akan meningkat.

Peningkatan nilai perusahaan dapat tercapai apabila ada kerja sama antara manajemen perusahaan dengan pihak lain yang meliputi sharehoder maupun stakeholder dalam membuat keputusankeputusan keuangan dengan tujuan memaksimumkan modal kerja yang dimiliki (Sukirni, 2012). Struktur modal atau kapitalisasi perusahaan adalah pembiayaan permanen yang terdiri dari hutang jangka panjang, saham preferen, dan modal pemegang saham, contohnya hutang jangka panjang, hutang jangka pendek, dan modal ekuitas (Weston dan Copeland, 2007). Menurut Gitman (2000), struktur modal (capital structure) merupakan kumpulan dana yang dapat digunakan untuk dialokasikan oleh perusahaan. Struktur modal juga dapat diartikan sebagai perimbangan atau perbandingan antara jumlah hutang jangka panjang dengan modal sendiri (Riyanto, 2008). Pendapat lain dikemukakan oleh Ross (1977) yang menyatakan bawa struktur modal (penggunaan hutang) merupakan sinyal yang disampaikan oleh manajer ke pasar.

Untuk dapat meminimalisir beban perusahaan akibat 
penggunaan hutang jangka penjang, maka solusi yang bisa ditempuh adalah dengan mengoptimalkan penggunaan struktur modal yang optimal. Menurut Riyanto (2008), struktur modal optimal merupakan struktur modal yang dapat meminimumkan biaya modal rata-rata dan memaksimumkan nilai perusahaan. Penelitian Utama dan Rohman (2013) menemukan bahwa Leverage yang diukur dengan debt to equity berpengaruh terhadap nilai saham.

Likuiditas dapat diartikan sebagai tingkat kemampuan suatu perusahaan untuk dapat membayar hutanghutangnya yang telah jatuh tempo (Kasmir, 2013). Menurut Mamduh (2004), likuiditas secara umum diartikan sebagai kemampuan suatu perusahaan memenuhi kewajiban keuangannya dalam jangka pendek atau yang harus segera dibayar. Menurut Titman et al. (2014), likuiditas adalah "the speed with which the asset can be converted into cash without loss of value." Kecepatan dimana aset dapat dikonversi menjadi uang tunai tanpa kehilangan nilai. Liquidity ratio adalah "measures of the ability of a firm to pay its bills in a timely manner when they come due". Likuiditas merupakan ukuran kemampuan perusahaan untuk membayar tagihannya secara tepat waktu ketika tanggal pembayaran sudah tiba waktunya. Penelitian Ulupui (2005) yang menguji pengaruh rasio likuiditas, leverage, aktivitas, dan profitabilitas terhadap return saham (studi pada perusahaan makanan dan minuman dengan kategori industri barang konsumsi di BEJ), hasilnya menunjukkan bahwa current ratio sebagai proksi likuiditas memiliki pengaruh positif dan signifikan terhadap return saham. Dilihat dari pihak emiten (manajemen perusahaan), LDR merupakan faktor yang cukup penting dalam kegiatan usaha suatu perusahaan perbankan. Ukuran perusahaan bisa dilihat dengan menggunakan total aktiva, penjualan atau modal dari perusahaan tersebut (Nasser, 2003). Dengan demikian, pihak manajemen harus dapat menjaga rasio LDR pada tingkat yang aman (sesuai dengan yang ditetapkan Bank Indonesia, yaitu 80-110\%). Dengan optimalnya LDR maka dalam kegiatan usahanya, bank akan selalu memperoleh keuntungan. Tingkat likuiditas suatu bank mempunyai pengaruh yang cukup signifikan terhadap besar kecilnya perolehan laba bank. Apabila bank dalam menyalurkan kredit dari dana pihak ketiganya tinggi maka otomatis likuiditasnya tinggi dan pendapatan bunganya akan tinggi.
Sudah ada beberapa penelitian yang menyinggung beberapa hal yang dibahas dalam penelitian ini. Utama dan Rohman (2013) menguji pengaruh Corporate Governance Perception Index (CGPI), profitabilitas, Leverage dan ukuran perusahaan terhadap nilai saham perusahaan yang terdaftar di Bursa Efek Indonesia periode 2007-2011. Data sampel menggunakan enam perusahaan. Model regresi yang digunakan dalam penelitian ini adalah regresi berganda. Hasil penelitian menunjukkan profitabilitas, leverage, dan ukuran perusahaan berpengaruh signifikan terhadap nilai saham. Sementara itu, tata CGPI tidak berpengaruh terhadap nilai saham.

Putu et al. (2014) meneliti pengaruh CSR, Corporate Governance, dan Ukuran perusahaan terhdap profitabilitas dan nilai perusahaan pada perusahaan Manufaktur yang terdaftar di Bursa Efek Indonesia. Sampel menggunakan 42 perusahaan. Metode analisis penelitian ini adalah analisis jalur menggunakan Partial Least Square (PLS). Hasil penelitian menunjukkan bahwa CSR, Corporate Governance, dan ukuran perusahaan berpengaruh positif terhadap profitabilitas. Tanggung jawab sosial perusahaan, corporate governance, ukuran perusahaan, dan profitabilitas berpengaruh positif terhadap nilai firm.

Tujuan dari penelitian ini adalah untuk mengetahui dan memformulasi rekomendasi pengaruh profitabilitas, struktur modal dan likuiditas terhadap nilai perusahaan pada bank yang go public periode tahun 2011-2014. Ruang lingkup dalam penelitian ini menggunakan sampel bank yang terdaftar di BEI untuk periode 20112015.

\section{METODE PENELITIAN}

Jenis penelitian ini adalah penelitian kausal yang bertujuan mengetahui hubungan antar beberapa variabel. Pendekatan yang digunakan dalam penelitian ini adalah pendekatan kuantitatif, yaitu untuk mencari apakah terdapat pengaruh yang signifikan antara variabel independen dengan variabel dependen pada subyek penelitian yang khusus. Pendekatan penelitian yang bersifat obyektif, mencakup pengumpulan data dan analisis data kuantitatif serta menggunakan metode pengujian statistik. Variabel yang diteliti meliputi profitabilitas yang diproksi dengan mengunakan rasio ROE, struktur modal yang diproksi dengan 
DER, likuiditas yang diproski dengan LDR, dan nilai perusahaan yang diproksi dengan PBV.

Jenis data yang digunakan dalam penelian ini adalah data sekunder. Data sekunder merupakan data primer yang telah diolah lebih lanjut dan disajikan baik oleh pihak pengumpul data primer atau oleh pihak lain yang digunakan oleh peneliti untuk diproses lebih lanjut. Sedangkan berdasarkan waktu pengumpulannya, data yang digunakan adalah data panel. Penelitian ini menggunakan data laporan keuangan perbankan yang terdiri dari laporan neraca dan laporan laba rugi serta rasio keuangan perbankan pada bank yang terdaftar di BEI untuk periode tahunan 2011-2014 yang berjumlah 30 sampel. Analisis data yang digunakan adalah analisis statistic inferensial.

Pada penelitian ini, untuk menjawab rumusan masalah digunakan konsep dan teori yang berkaitan dengan nilai perusahaan, profitabilitas, struktur modal dan likuiditas. Variabel dependen dalam penelitian ini adalah nilai perusahaan. Variabel independennya adalah profitabilitas, struktur modal dan likuiditas.

Salah satu pengembangan dari analisis regresi adalah regresi data panel (Ratnasari et al. 2014). Penelitian ini menggunakan analisis regresi data panel yang diolah dalam Ms. Excel dan dianalisis dengan menggunakan software eviews 8. Dalam metode data panel pada eviews, secara umum terbagi menjadi empat bagian, yaitu (1) persiapan / input data, (2) estimasi regresi data panel, (3) pemilihan model regresi data, (4) penyembuhan heteroskedastisitas. Pada bagian pemilihan model regresi data, dilakukan setelah pemilihan model yang tepat atau sesuai dengan tujuan penelitian telah didapatkan. Ada tiga uji yang dapat dijadikan alat dalam memilih model regresi data panel (Model Common Effect, Fixed Effect dan Random Effect) berdasarkan karakteristik data yang dimiliki, yaitu F Test (Chow Test), Hausman Test dan Langrangge Multiplier (LM) Test. Pengujian dengan menggunakan regresi dapat dilaksanakan setelah memenuhi asumsi klasik.

Regresi data panel memberikan alternatif model, Common Effect, Fixed Effect dan Random Effect. Model Common Effect dan Fixed Effect menggunakan pendekatan OLS dalam teknik estimasinya, sedangkan Random Effect menggunakan Generalized Least Squares (GLS) sebagai teknik estimasinya. Uji asumsi klasik yang digunakan dalam regresi linier dengan pendekatan OLS pada penelitian ini meliputi uji, Heteroskedastisitas, Multikolinieritas dan Normalitas.

Pengujian hipotesis ditujukan untuk mengetahui bagaimanakah pengaruh dan arah hubungan variabelvariabel dependen terhadap variabel independen baik secara bersama-sama maupun secara parsial. $\mathrm{R}^{2}$ digunakan untuk mempresentasikan kembali proporsi dari varian variabel independen dan keterhubungannya dengan variabel independen lainnya pada model O'brien (2007). Pengujian hipotesis ini dilakukan melalui analisis regresi berganda, uji koefisien determinasi $\left(\mathrm{R}^{2}\right)$, uji regresi simultan (uji F) dan uji regresi parsial (uji t). Model analisis regresi berganda dirumuskan dengan persamaan berikut :

$$
\mathrm{Y}=\mathrm{a}+\mathrm{b} 1 \mathrm{X} 1+\mathrm{b} 2 \mathrm{X} 2+\mathrm{b} 3 \mathrm{X} 3+\ldots+\mathrm{bnXn}
$$

Keterangan: Y nilai perusahaan (PBV)); X1 (profitabilitas (ROE)); X2 (struktur modal (DER)); X3(likuiditas (LDR)).

Pada uji koefisien determinasi, Nilai $\mathrm{R}^{2}$ yang baik adalah lebih dari 50\%, karena berarti sampel yang digunakan untuk regresi bisa merepresentasikan setidaknya setengah dari total populasi, dan mampu menjelaskan secara lebih relevan. Pada uji regresi simultan (uji F), Jika nilai $\mathrm{C}<0$ maka ini berarti bahwa secara simultan semua variabel independen tersebut tidak mempunyai pengaruh yang negatif terhadap variabel dependen sedangkan jika nilai probabilitas di bawah 5\%, maka ini berarti bahwa variabel independen yang digunakan adalah variabel yang secara signifikan penting dalam mempengaruhi variabel dependen. Untuk uji regresi parsial (uji t), Jika probabilitas $>0,05$ maka secara parsial variabel independen tidak mempunyai pengaruh signifikan terhadap variabel dependen dan apabila probabilitas $<0,05$ maka secara parsial variabel independen mempunyai pengaruh signifikan terhadap variabel dependen. Kerangka pemikiran penelitian selengkapnya pada Gambar 1.

Berdasarkan uraian kerangka pemikiran maka dapat dirumuskan hipotesis penelitian sebagai berikut:

H1 : profitabilitas (ROE) berpengaruh positif terhadap nilai perusahaan (PBV)

H2 : struktur modal (DER) berpengaruh positif terhadap nilai perusahaan (PBV)

H3 : likuiditas (LDR) berpengaruh positif terhadap nilai perusahaan (PBV) 


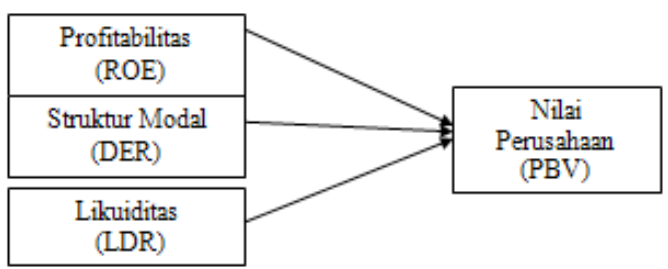

Gambar 1. Kerangka pemikiran penelitian

\section{HASIL}

\section{Pengaruh ROE, DER dan LDR Terhadap PBV}

Data dari ROE, DER, LDR dan PBV telah disusun dengan format yang sesuai dengan eviews 8 dengan nama perusahaan (firm) pada kolom pertama. Nama perusahaan di sini adalah perusahaan sampel yang diambil berdasarkan data bank go public yang terdaftar di BEI. Pada kolom dua, diisi periode atau tahun penggunaan data yang pada penelitian ini adalah tahun 2011-2014.Untuk kolom ke tiga, empat, lima dan selanjutnya diisi data variabel terikat dan variabel bebas. Data yang telah disusun pada Microsoft excel, di masukkan pada template eviews 8 .

Pada tahap estimasi regresi data panel yang telah dilakukan, model yang ingin dibentuk adalah model fixed effect (FE). Setelah dipilih modelnya, maka perlu dilakukan uji kesesuaian model regresi.

Pada uji chow test, didapatkan data bahwa nilai probabilitas $0,00<0,05$ sehingga dapat disimpulkan bahwa model FE lebih tepat dibandingkan dengan model CE. Dari hasil output penelitian terlihat bahwa nilai Prob. Cross-section random sebesar 0,098 yang nilainya $>0,05$ sehingga dapat disimpulkan bahwa model RE lebih tepat dibandingkan dengan model FE untuk penelitian ini. Dari dua uji pemilihan model ini didapatkan hasil yang berbeda sehingga harus dilakukan uji selanjutnya, yaitu Langragge Test (LM). Nilai Chi Squared tabel, chi squared pada derajat kebebasan 2 dan alpha 5\% adalah 7,815. Pada output hasil penelitian didapatkan nilai Breusch Paqan atau data LM hitung sebesar 16,831 atau lebih besar dari pada nilai chi squared $(7,815)$. Berdasarkan hal tersebut, maka dapat disimpulkan bahwa model RE lebih tepat dibandingkan dengan model FE untuk penelitian ini. Berdasarkan ketiga test di atas maka model yang digunakan dalam penelitian adalah Model RE.
Pengujian hipotesis ini dilakukan melalui analisis regresi berganda, Uji koefisien Determinasi (R2), Uji regresi Simultan (uji F) dan Uji regresi Parsial (uji t). Pada uji koefisien determinasi $\left(\mathrm{R}^{2}\right)$ nilai adjusted koefisien determinasi $\left(\mathrm{R}^{2}\right)$ adalah 0,799 atau dengan kata lain bahwa sampel dalam regresi ini mampu merepresentasikan total populasi sebesar kurang lebih $79,9 \%$. Dapat dikatakan bahwa sampel dapat secara baik merepresentasikan total populasi. Untuk uji $\mathrm{F}$ diketahui nilai Fstatistik adalah 15,792 dan untuk probabilitas sebesar 0,00 atau lebih kecil dari 5\% sehingga dapat dikatakan bahwa secara keseluruhan, variabel-variabel independen (ROE, DER dan LDR) bersama-sama berpengaruh secara signifikan terhadap variabel dependen (PBV). Sedangkan pada uji t penelitian, maka dapat disusun persamaan seperti berikut ini:

$$
\begin{aligned}
\mathrm{PBV}= & 1,659+1,117 \mathrm{ROE}-0,021 \mathrm{DER}+0,002 \mathrm{LDR} \\
& +\mathrm{e}
\end{aligned}
$$

Keterangan: PBV (Nilai perusahaan); ROE (Profitabilitas); DER (Struktur Modal); LDR (Likuiditas); e(Error).

Nilai C dan prob masing-masing variabel independen, berdasarkan persamaanhasilujitdapatdikatakan bahwa: Nilai probabilitas untuk variabel profitabilitas atau ROE adalah 0,048 atau lebih kecil dari 5\%, sedangkan nilai Cnya adalah 1,117. Hal ini dapat dikatakan bahwa profitabilitas (ROE) berpengaruh signifikan terhadap PBV karena nilai probabilitas lebih kecil dari 0,05 dengan arah hubungan positif. Selanjutnya, nilai probabilitas untuk variabel struktur modal atau DER adalah 0,414 atau lebih besar dari 5\%, sedangkan nilai Cnya adalah $-0,021$. Hal ini dapat dikatakan bahwa struktur modal (DER) tidak berpengaruh signifikan terhadap PBV karena nilai probabilitas lebih besar dari 0,05 dengan arah hubungan negatif. Di sisi lain, nilai probabilitas untuk variabel likuiditas atau LDR adalah 0,863 atau lebih besar dari 5\%, sedangkan nilai $\mathrm{C}$ nya adalah 0,002 . Hal ini dapat dikatakan bahwa likuiditas (LDR) tidak berpengaruh signifikan terhadap PBV karena nilai probabilitas lebih besar dari 0,05 dengan arah hubungan positif.

\section{Pengaruh ROE Terhadap PBV}

Dari hasil penelitian ini menyatakan bahwa return on equity (ROE) berpengaruh positif dan signifikan terhadap PBV sehingga hipotesis pertama $(\mathrm{H} 1)$ diterima. 
Hasil ini sama dengan hasil penelitian dari Utama dan Rohman(2013)yang menunjukkan bahwa profitabilitas, leverage, dan ukuran perusahaan berpengaruh signifikan terhadap nilai saham. Perusahaan perlu memperhatikan dan terus meningkatkan ROE dengan cara meningkatkan labanya. Hasil ROE menyatakan bahwa perusahaan menghasilkan dalam kondisi yang menguntungkan, sehingga apabila ROEnya tinggi akan memberikan sinyal positif pada investor. Hal ini merupakan daya tarik investor untuk memiliki saham perusahaan. Permintaan saham yang tinggi akan secara langsung meningkatkan nilai perusahaan. Dengan demikian ROE berpengaruh positif dan signifikan terhadap nilai perusahaan. Hal ini bertentangan dengan penelitian yang dilakukan oleh Sari dan Ardiana (2014) yang mengatakan bahwa struktur pendanaan, profitabilitas dan komite audit berpengaruh negatif tidak signifikan terhadap nilai perusahaan

\section{Pengaruh DER Terhadap PBV}

Dari hasil analisis regresi dapat diketahui bahwa DER berhubungan negatif dan tidak signifikan terhadap PBV sehingga hipótesis yang kedua (H2) ditolak. Hal ini berarti perusahaan-perusahaan perbankan menggunakan modal yang terdiri atas hutang sedangkan diketahui bahwa penggunaan hutang yang tinggi akan menyebabkan timbulnya biaya kebangkrutan dan beban bunga yang semakin besar. Apabila biaya kebangkrutan semakin besar, maka biaya modal hutang akan semakin tinggi karena pemberi pinjaman akan membebankan bunga. Akan tetapi hal tersebut terkadang tidak dikuatirkan oleh perusahaan karena apabila manfaat hutang masih lebih besar dibandingkan dengan biaya kebangkrutan maka perusahaan akan terus menggunakan hutang.

\section{Pengaruh LDR Terhadap PBV}

Dari hasil analisis regresi dapat diketahui bahwa LDR berhubungan positif dan tidak signifikan terhadap PBV sehingga hipotesis yang ketiga (H3) diterima. Likuiditas yang tinggi dapat menimbulkan resiko biaya modal yang rendah apabila dana-dana di perusahaan dapat digunakan dengan baik, sehingga investor akan melihat itu sebagai sinyal positif. Kondisi ini dapat diartikan bahwa, nilai aktiva lancar (yang segera dapat dijadikan uang) dengan perbandingan hutang jangka pendek memberikan pengaruh positif dalam meningkatkan nilai perusahaan.
Pada hasil penelitian terlihat bahwa nilai probabilitas terbesar adalah ROE jika dibandingkan dengan variabel independen lainnya. Variabel ROE merupakan variabel yang terbaik untuk digunakan dalam menentukan nilai perusahaan. Perusahaan yang mempunyai kinerja keuangan atau profitabilitas (ROE) baik akan berdampak pada harga sahamnya akan semakin baik, dengan demikian jika harga saham perusahaan naik maka keuntungan akan dapat dinikmati oleh investor.

\section{Implikasi Manajerial}

Sesuai hasil penelitian terhadap hubungan antara variabel ROE, DER dan LDR terhadap PBV, maka implikasi manajerial penelitian ini adalah sebagai berikut:

\section{Pihak Manajemen Perusahaan}

Temuan variabel profitabilitas (ROE) yang positif dan signifikanterhadapnilaiperusahaan(PBV)menunjukkan manajemen perusahaan telah berhasil meningkatkan nilai perusahaan sesuai dengan tujuan manajemen keuangan memaksimumkan nilai perusahaan. Manajemen perusahaan dapat meningkatkan potensi peningkatan keuntungan dengan mengembangkan prospek kegiatan yang telah dilakukan perusahaan agar dapat menjadi lebih produktif dari sebelumnya. Sehingga para investor dapat tertarik dan merasakan keuntungan yang lebih besar dari modal yang mereka keluarkan.

Setiap perusahaan membutuhkan dana untuk kegiatan operasional dan mencakup kinerja perusahaan (Sandy dan Asyik 2013). Dari hasil penelitian didapatkan bahwa debt to equity ratio (DER) atau struktur modal berpengaruh negatif dan tidak signifikan terhadap price book value (PBV) atau nilai perusahaan. Perusahaan yang memiliki free cash flow tinggi akan digunakan manajer untuk investasi yang menghasilkan return positif, sehingga dapat meningkatkan nilai perusahaan dimasa mendatang (Mardasari, 2014). Hutang yang berjumlah besar juga akan menyebabkan perusahaan akan semakin terbeban dalam pembayaran beban bunga. Hal tersebut secara tidak langsung akan menimbulkan risiko kebangkrutan. Perusahaan harus memperhatikan keseimbangan dalam cara pemenuhan kebutuhan dana, jangan sepenuhnya dibiayai dengan hutang. Untuk mengajukan hutang dalam struktur modal, perusahaan harus mempertimbangkan manfaat yang diperoleh untuk perusahaan. 
Pihak Investor

Seorang investor memerlukan berbagai macam informasi kinerja keuangan perusahaan untuk mengurangi risiko dan kondisi ketidakpastian yang terjadi (Pertiwi, 2014). Investor dalam menanamkan dana dipasar modal memiliki tujuan jangka pendek dan jangka panjang. Tujuan jangka pendek yang ingin dicapai adalah capital gain, yaitu selisih antara harga beli saham dan harga jual saham, sedangkan tujuan jangka panjang dari investasi adalah dividen yaitu keuntungan yang akan diperoleh perlembar saham (Ismayanti, 2014). Semakin tinggi harga saham semakin tinggi pula nilai perusahaan dan kemakmuran pemegang saham makin tinggi (Mahendra et al. 2012). Oleh karena itu, investor sebaiknya selalu memperhatikan dan menggunakan informasi tentang kinerja perusahaan (emiten) dari sisi rasio aktivitas dan rasio profitabilitas serta informasi pasar. Hal ini dimaksudkan agar investor dapat mengambil keputusan yang tepat dalam berinvestasi. Likuiditas atau LDR dapat dijadikan acuan untuk menentukan strategi investasi karena merupakan salah satu faktor yang menentukan bahwa bank tersebut sehat atau tidak. Bank Indonesia selaku pihak regulator selalu memantau LDR perbankan yang tercatat di BEJ agar kinerja keuangan yang dicapai bank-bank tersebut dapat meningkat. Semakin likuid suatu bank, maka dapat disimpulkan kelangsungan hidup bank tersebut akan berlangsung lama. Dengan demikian, investor akan tertarik untuk berinvestasi di bank tersebut.

\section{KESIMPULAN DAN SARAN}

\section{Kesimpulan}

Dari hasil penelitian menyatakan bahwa return on equity (ROE) berpengaruh positif dan signifikan terhadap PBV sehingga perusahaan perlu memperhatikan dan terus meningkatkan ROE dengan cara mengambangkan prospek kegiatan dalam rangka untuk peningkatan laba. Nilai probabilitas terbesar adalah ROE jika dibandingkan dengan variabel independen lainnya. Oleh karena itu ROE dapat dipakai sebagai prediktor dalam memprediksi tentang nilai perusahaan.

\section{Saran}

Mengacu pada keterbatasan yang ditemukan dalam penelitian ini, maka saran yang dapat diberikan untuk penelitian selanjutnya adalah agar dapat mengembangkan ukuran perusahaan dalam penentuan sampel, sehingga dapat diketahui pengaruh variabel yang sama terhadap nilai perusahaan dari jenis perusahaan dan sudut pandang yang berbeda. Selain itu, penelitian selanjutnya dapat menambahkan faktor eksternal yang dapat mempengaruhi nilai perusahaan, seperti tingkat suku bunga, tingkat inflasi dan nilai kurs, dan lain sebagainya sehingga dapat memberikan kesimpulan secara menyeluruh mengenai pengaruhnya terhadap nilai perusahaan.

Saran kepada para investor maupun calon investor jika ingin berinvestasi pada perusahaan perbankan agar melihat dan menganalisa variabel yang vital dan fundamental yang berpengaruh terhadap nilai perusahaan secara keseluruhan.

\section{DAFTAR PUSTAKA}

Andini NWL, Wirawati NGP. 2014. Pengaruh cash flow pada kinerja keuangan dan implikasinya pada nilai perusahaan manufaktur. E-Jurnal Akuntansi Universitas Udayana 7(1): 107-121.

Dominick S. 2005. Ekonomi Manajerial dalam Perekonomian Global. Jakarta: Salemba Empat

Ismayanti D. 2014. Pengaruh fundamental dan risiko (beta) terhadap return saham pada perusahaan yang termasuk dalam indeks LQ 45. Jurnal Wawasan Manajemen 2(1): 1-20.

Kasmir. 2013. Bank dan Lembaga Keuangan Lainnya. Ed rev 2008. Jakarta: Raja Grafindo Press.

Mahendra DJ A, Artini LGS, Suarjaya AAG. 2012. Pengaruh kinerja keuangan terhadap nilai perusahaan pada perusahaan menufaktur di bursa efek Indonesia. Jurnal Manajemen, Strategi Bisnis dan Kewirausahaan 6 (2): 130-138.

Mamduh HM. 2004. Manajemen Keuangan. Yogyakarta: BPFE

Mardasari RB. 2014. Pengaruh insider ownership, kebijakan hutang dan free cash flow terhadap nilai perusahaan melalui kebijakan dividen. Jurnal Ilmu Manajemen 2(4): 1807-1820.

O'Brien. R. M. 2007. A caution regarding rules of thumb for variance inflation factor. Quality \& Quantity Journal 4(1): 637-690. https://doi.org/10.1007/ s11135-006-9018-6.

Pertiwi NT. 2016. Pengaruh profitabilitas, kepemilikan manajerial, DER dan FCF terhadap nilai perusahaan melalui DPR. Jurnal Ilmu dan Riset 
Akuntansi 5 (2): 1-25.

Putu, Martini NG, Moeljadi, Djumahir, Djazuli A. 2014. Factors affecting firms value of Indonesia public manufacturing firms. International Journal of Business and Management Invention 3(2): 35-44.

Ratnasari NPAM, Kencana IPEN, Gandhiadi GK. 2014. Aplikasi regresi data panel dengan pendekatan fixed effect model (studi kasus PT PLN Ginanyar). E-jurnal Matematika 3(1): 1-7. https://doi.org/10.24843/MTK.2014.v03.i01. p059.

Riyanto B. 2008. Dasar-dasar Pembelanjaan Perusahaan. Ed ke-4. Yogyakarta: BPFE.

Ross SA. 1977. The Determination of finacial structure: the incentive signalling approach. Journal of Economics 8(1): 23-40.

Saidi. 2004. Faktor-faktor yang memengaruhi struktur modal pada perusahaan manufaktur go public di BEJ Tahun 1997-2002. Jurnal Bisnis dan Ekonomi 11(1):44-58.

Sandy A, Asyik NF. 2013. Pengaruh profitabilitas dan likuiditas terhadap kebijakan dividen kas pada perusahaan otomotif. Jurnal Ilmu dan Riset Akuntansi 1(1): 58-76.

Sari AAPA, Ardiana PA. 2014. Pengaruh board size terhadap nilai perusahaan. E-Jurnal Akuntansi Universitas Udayana 7(1):177-191.

Soliha E, Taswan. 2002. Pengaruh kebijakan hutang terhadap nilai perusahaan serta beberapa faktor yang memengaruhinya. Jurnal Bisnis dan Ekonomi 9(2): 149-163.

Sujoko, Soebiantoro U. 2007. Pengaruh struktur kepemilikan, leverage, faktor intern, dan faktor ekstern terhadap nilai perusahaan (studi empirik pada perusahaan manufaktur dan non manufaktur di bursa efek Jakarta). Jurnal Manajemen dan Kewirausahaan 9(1): 41-49.

Sukirni D. 2012. Kepemilikan manajerial, kepemilikan institusional, kebijakan deviden dan kebijakan hutang analisis terhadap nilai perusahaan. Accounting Analysis Journal 1(2): 1-12.

Titman, Sheridan, KeownAJ, MartinJD.2014. Financial Management Principles and Applications, Ed ke-12. Edinburgh: Pearson.

Triagustina L, Sukarmanto E, Helliana. 2015. Pengaruh return on asset (ROE) dan return on equity (ROE) terhadap nilai perusahaan pada perusahaan manufaktur subsector makanan dan minuman yang terdaftar di bursa efek Indonesia periode 2010-2012. Prosiding Penelitian Sivitas Akademika Unisba (Sosial dan Humaniora) (2): 28-34.

Ulupui IGKA. 2005. Analisis pengaruh rasio likuiditas, Leverage, aktivitas, dan profitabilitas terhadap return saham: studi pada perusahaan makanan dan minuman dengan kategori industri barang konsumsi yang terdaftar di bursa efek Jakarta. Audi Jurnal Akuntansi dan Bisnis 2(1):19073771.

Utama AT, Rohman A. 2013. Pengaruh corporate governance perception Index, profitabilitas, Leverage, dan ukuran perusahaan terhadap nilai saham. Diponegoro Journal of Accounting 3(1): 1-9.

Wahyudi U, Pawestri PH. 2006. Implikasi struktur kepemilikan, terhadap nilai perusahaan dengan keputusan keuangan sebagai variabel intervening. Simposium Nasional Akuntansi 9 Padang. Padang: KAKPM 17.

Weston, Copeland. 2002. Manajemen Keuangan. Ed ke-8. Jakarta: Binarupa Aksara. 